УДК 811.111+811.161.2]'25

DOI https://doi.org/10.26661/2414-1135-2021-82-15

\title{
КАТЕГОРІЯ ВОЛІ У ФРАЗЕОЛОГІЇ РІЗНОСПОРІДНЕНИХ МОВ: ЛІНГВОКУЛЬТУРНИЙ І ПЕРЕКЛАДАЦЬКИЙ АНАЛІЗ
}

\author{
Канна В. Ю. \\ кандидат філологічних наук, дочент, \\ дочент кафедри теорії та практики перекладу \\ Маріупольський державний університет \\ пр. Будівельників, 129, Маріуполь, Донецька область, Україна \\ orcid.org/0000-0001-7079-3542 \\ victkanna@gmail.com \\ Панова Я. С. \\ старший викладач кафедри теорії та практики перекладу \\ Маріупольський державний університет \\ пр. Будівельників, 129, Маріуполь, Донечька область, Україна \\ orcid.org/0000-0002-0488-5462 \\ yanapanova80@gmail.com \\ Лучина С. М. \\ асистент кафедри теорії та практики перекладу \\ Маріупольський державний університет \\ пр. Будівельників, 129, Маріуполь, Донецька область, Украӥна \\ orcid.org/0000-0002-4756-2874 \\ s.luchyna@mdu.in.ua
}

Ключові слова: прислів'я, менталітет, вольовий стан, вольова дія, семантика, переклад.
Стаття присвячена дослідженню лінгвокультурних i перекладацьких характеристик прислів ”ї на позначення тематичного складника «воля» в різноспоріднених мовах. Проаналізовано прислів'я в англійській, українській і новогрецькій мовах за основними вольовими категоріями й виявлено головні риси національного менталітету кожного 3 трьох народів. У паремійному фонді української мови найбільше прислів ”їв на позначення наполегливості й рішучості, далі йдуть вольові стани байдужості, покірливості, упертості, цілеспрямованості та піддатливості впливу; найрідше в українських прислів'ях зустрічаються слабовілля й сила волі. В англійських прислів'ях найчастіше відображені наполегливість i піддатливість впливу. Вольові стани покірливості, слабовілля, цілеспрямованості й рішучості посідають чільне місце в семантиці англійськихприслів ’ї,хочаприслів 'ївнапозначенняупертостітабайдужості не так багато. Прислів'я, що відображають силу волі, в англійській мові практично не зустрічаються. У новогрецькій мові найчастіше вживаються прислів'я на позначення наполегливості й байдужості. Далі йдуть вольові стани піддатливості впливу та покірливості. У семантиці новогрецьких прислів'їв відображено вольові категорії цілеспрямованості, сили волі та слабовілля. Найменш розкритими вольовими поняттями в новогрецькому паремійному фонді мови виявилися рішучість і впертість.

Таким чином, відмінність семантики англійських, українських і новогрецьких прислів”їв на позначення вольових дій і станів людини пояснюється тим, що в кожного народу різні системи поглядів людини на себе та своє місце у світі, а отже, відрізняється й національний менталітет. Тим не менше спільні риси вказують на аналогічність мислення та схожість рис національного характеру, подібність естетично-логічної оцінки навколишнього світу.

Установлено. що найбільш уживаними способами перекладу прислів'їв $є$ описовий переклад, частковий еквівалентний переклад і повний прислівний еквівалент, найменш уживаними виявилися калька та дослівний переклад. 


\title{
THE CATEGORY OF WILL IN THE PHRASEOLOGY OF NONCOGNATE LANGUAGES: LINGUISTIC, CULTURAL AND TRANSLATION ANALYSIS
}

\author{
Kanna V. Yu. \\ Candidate of Philological Sciences, Associate Professor, \\ Associate Professor at the Theory and Practice of Translation Department \\ Mariupol State University \\ Budivelnykiv avenue, 129, Mariupol, Ukraine \\ orcid.org/0000-0001-7079-3542 \\ victkanna@gmail.com \\ Panova Ya. Ye. \\ Senior Lecturer at the Theory and Practice of Translation Department \\ Mariupol State University \\ Budivelnykiv avenue, 129, Mariupol, Ukraine \\ orcid.org/0000-0002-0488-5462 \\ yanapanova80@gmail.com \\ Luchina S. M. \\ Assistant Lecturer at the Theory and Practice of Translation Department \\ Mariupol State University \\ Budivelnykiv avenue, 129, Mariupol, Ukraine \\ orcid.org/0000-0002-4756-2874 \\ s.luchyna@mdu.in.ua
}

Key words: proverbs, mentality, volitional state, volitional action, semantics, translation.
The paper is devoted to the study of linguistic, cultural and translation characteristics of proverbs denoting the category of "will" in noncognate languages.

Proverbs in the English, Ukrainian and Modern Greek languages are analysed and the main features of the national mentality of each of the three peoples are revealed. The biggest group in the paremic stock of the Ukrainian language is constituted by proverbs denoting persistence and determination, they are followed by the states of indifference, obedience, stubbornness, purposefulness and compliance. There are few Ukrainian proverbs about the strength of will and weakness of will. English proverbs frequently denote persistence and compliance. The volitional states of obedience, weak will, purposefulness and determination are common to the semantics of English proverbs, although there are not many proverbs denoting stubbornness and indifference. However, there are almost no proverbs reflecting willpower in English, In Modern Greek proverbs denoting persistence and indifference are most common. This is followed by volitional states of compliance. and obedience. The semantics of modern Greek proverbs reflect the volitional categories of purposefulness, strength of will and weakness of will. Determination and stubbornness are least common volitional notions in the Modern Greek language.

Thus, the difference in the semantics of English, Ukrainian and modern Greek proverbs denoting volitional actions and states is explained by the fact that each nation has its own system of self-identification in the world which results in a different national mentality. But the common features indicate similar way of thinking and features of national identity, similar esthetic and logical evaluation of the surrounding world.

It is determined that the most frequently used ways of translation of the abovementioned proverbs are descriptive translation, partial equivalent translation and full proverbial equivalent, the least used methods are loan translation and literal translation. 
Постановка проблеми. Серед нових напрямів розвитку сучасної лінгвістики в окреме русло виділяються дослідження пареміологічного фонду мови як віддзеркалення національної культури. Мовознавці почали приділяти увагу ретельним дослідженням паремій тільки в останній чверті XIX століття. Збором, систематизацією, класифікацією та теоретичними розробками паремійних одиниць займалося багато вчених-лінгвістів. Серед вітчизняних дослідників пареміології варто зазначити О.О. Потебню [1], О.В. Куніна [2], В.В. Виноградова [3], Г.Л. Пермякова [4], а серед зарубіжних - Д. Лукатоса [5], А.Л. Куусі [6], М. Тріандафілідіса [7], П. Хараламбоса [8] та ін.

Незважаючи на наявність значної кількості лінгвокульторологічних і перекладацьких студій, зроблено недостатньо спроб дослідження прислів 'їв на матеріалі різноспоріднених мов з метою виявлення кореляцій у таких мовах і засобів перекодування прислів 'ів, що зумовлює актуальність роботи.

Мета й завдання роботи - здійснити лінгвокультурне дослідження та перекладацький аналіз прислів "їв 3 тематичним складником «воля» на матеріалі трьох мов, відстеживши спільні та відмінні риси українського, англійського й новогрецького менталітету, а також способи перекладу таких паремійних одиниць.

Об'єктом роботи є прислів'я на позначення категорії вольових дій і станів людини.

Предметом дослідження $\epsilon$ лінгвокультурні й перекладацькі характеристики прислів'їв на позначення вольових дій і станів людини.

Методи дослідження представлені методом суцільної вибірки, дескриптивним методом, методом компонентного (семантико-когнітивного) аналізу, порівняльним методом і кількісним методом.

За матеріал дослідження обрано суцільну вибірку прислів 'їв на позначення вольових дій i станів людини 3 фразеологічних словників української, англійської та новогрецької мов у кількості 234 одиниці.

Виклад основного матеріалу дослідження. Вольові дії та стани людини, які зазначені в прислів'ях, несуть інформацію про осмислення волі як сили, вони фіксують морально-вольові риси характеру, підкреслюють волелюбність народу. У фольклорній традиції українського, англійського та грецького народів знайшли своє багатогранне відображення прислів'я, які позначають вольові категорії ставлення людини до навколишнього світу й життєвих ситуацій. У семантиці таких паремій поняття волі часто переосмислюється, тому в прислів'ях здебільшого демонструються не вольові активні дії, а переважно зусилля та стани 3 негативним чи позитивним вольовим відтінком [4, с. 56]. Спираючись на тематичну класифікацію прислів'їв на позначення вольових дій і станів людини В.В. Федорова й тематичну класифікацію за тезаурусом, далі ми будемо аналізувати обрані нами прислів'я за такими вольовими ознаками.

Вольовий стан «наполегливість» означає стійкість, завзятість і непохитність у досягненні мети. Це одна 3 найхарактерніших рис українців, яка відображена в таких прислів'ях:

Де не можна перестрибнути, там перелізь (наполегливість у подоланні певних перешкод) [9];

Little strokes fell great oaks, тобто настирливість усе здолає [10].

Як показали результати семантичного аналізу паремій, «наполегливість» також є головним вольовим станом у новогрецьких прислів'ях. На це вказують такі новогрецькі прислів'я:

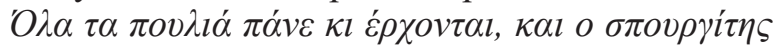

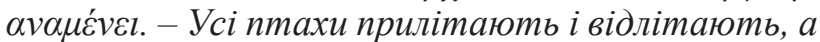
горобеиь залишається.

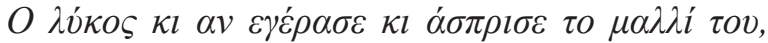

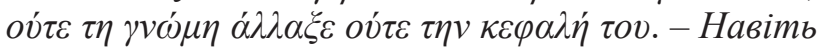
якщо вовк постарів і посивів, він ані своєї думки, ані голови не змінив [11].

Українському менталітету також притаманна морально-вольова риса характеру «рішучість». Ця риса національного характеру зустрічається в прислів'ях 3 опорними словами piщучість і сміливість:

Рішучість брами відкриває (подолання та припинення будь-яких вагань];

Сміливий, як жаба: з маху та в воду (рішучість у вчинку) [9].

Вольова категорія «рішучість» знайшла своє чітке відображення в паремійному фонді англійської мови. Англійський народ цінує та поважає вміння своєчасно й самостійно приймати відповідальні рішення, що підтверджують такі прислів'я:

As a man with plenty of guts - саме так говорять про вольову та рішучу людину [10].

Греки розуміють вольовий стан «рішучість» як прагнення відважитися скористатися можливістю в зручну мить, щоб спіймати успіх. Це наочно демонструє таке прислів'я:

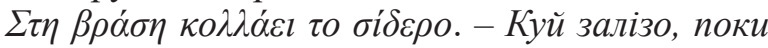
воно гаряче [11].

У грецькому менталітеті поняття рішучості сприймається не як сміливість і відважність, а як вольовий стан готовності до дій.

Чи не найголовнішою вольовою рисою національного характеру українців $є$ вперmicmb. Непоступливість, намагання робити все по-своєму, іноді наперекір здоровому глузду віддзеркалюються в таких прислів'ях:

Упертий як віл;

Не хочу в ворота, розбирайте тин;

Уперся як кілок у тин [9]. 
Окрім цього, українському національному характеру притаманний такий вольовий стан, як «байдужість», тобто незацікавленість у навколишньому середовищі, несхильність до почуттів i пристрастей. Досить часто в мовленні вживаються такі прислів'я:

Не моє просо, не мої горобиі, не буду відганяти (байдужість до того, що відбувається; людина навіть не намагається допомогти).

Наступне прислів'я має застережливу та повчальну мету, водночас воно критикує байдужість, яка взагалі не притаманна англійському національному менталітету:

A little neglect may breed great mischief. - Байдyжість може породити велике лихо[10].

Вольовий стан байдужості є одним із часто вживаних у семантиці вольових рис у новогрецьких прислів'ях. Варто зазначити, що байдужість у грецьких пареміях має відтінок апатичності незворушності щодо оточуючих, а іноді й людини до самої себе. Наприклад:

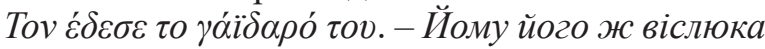
і прив'язав / Моя хата з краю, нічого не знаю [11].

Соціальне розшарування українського суспільства зумовило виникнення не тільки пасивності, байдужості, а й покірності. Це віддзеркалюється в таких прислів'ях:

Вези, кобило, хоч тобі не мило;

Куди дерево підрубане, туди воно й падає;

Куди коняка, туди й віз [9].

На відміну від українських прислів’їв, покірливість в англійських прислів'ях не має негативного підтексту. Навпаки, англійці вважають цю рису безцінною та притаманною лише їм, вони навіть порівнюють іiі 3 коштовністю:

Consistency is a jewel. - Покірність - чудова puca.

The wagon must go whither the horses draw it також означає покірливість, але 3 відтінком піддатливості впливу та покори[10].

Здатність коритися долі - одна з основних рис грецького національного характеру та вдачі. На це наочно вказує таке прислів'я на позначення вольової категорії «покірливість»:

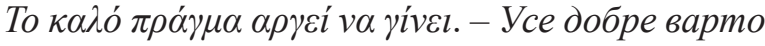
почекати [11].

У цьому випадку паремія спонукає надіятися на краще, трішки зачекати та змиритися із ситуацією, тобто коритися волі. Однак новогрецькі прислів'я, як виявилося, можуть показувати покірливість з точки зору неминучості й вимушеності подій. Наприклад:

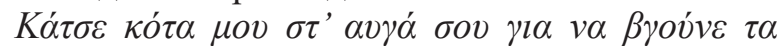

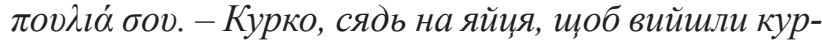
чаma [11].

В українському паремійному фонді досить часто зустрічаються прислів'я на позначення вольової категорії «піддатливість впливу», що продемонстровано на прикладі таких прислів 'їв:

Куди одна вівия, туди i вся отара (однозначна піддатливість впливу у вчинках; «стадний інстинкт»);

Сім n'ятниць на тиждень (нерішучість у своїх діях, невпевненість у правильності своїх намірів і, як наслідок, піддатливість будь-якому впливу) [9].

Піддатливість вПливу, схильність людини до зміни своїх поглядів і думок під впливом більш упевнених у собі особистостях є головним вольовим станом в англійських прислів'ях. Ця риса формує вольовий менталітет англійців. Підтвердженням цього є такі прислів'я:

If a sheep loops the dyke, all the rest will follow.Куди одна вівия, туди і вся отара;

Open not your door when devil knocks. - He nidдавайся спокусі [10].

Вольова категорія «піддатливість впливу» також посідає чільне місце в семантиці новогрецьких прислів”їв. Досить часто в повсякденному мовленні греків зустрічаються такі синонімічні прислів'я:

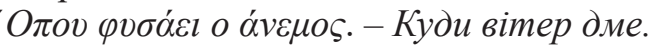

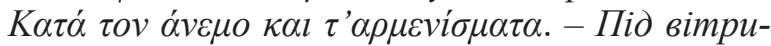
лами йдуть за напрямком вітру [11].

Проаналізувавши прислів'я на позначення вольових дій і станів людини в англійській, українській i новогрецькій мовах, ми виявили найхарактерніші риси менталітетів цих народів. У паремійному фонді української мови найбільше прислів “їв на позначення наполегливості й рішучості, далі йдуть вольові стани байдужості, покірливості, упертості, цілеспрямованості й піддатливості впливу; найрідше в українських прислів'ях зустрічаються вольові стани «слабовілля» та «сила волі». В англійських прислів'ях найчастіше відображені наполегливість і піддатливість впливу. Вольові стани покірливості, слабовілля, цілеспрямованості й рішучості посідають чільне місце в семантиці англійських прислів”їв, тоді як прислів ’їв на позначення упертості й байдужості не так багато. Зазначимо, що в англійській мові практично не зустрічаються прислів'я, які відображають силу волі.

У новогрецькій мові найчастіше вживаються прислів'я на позначення наполегливості й байдужості. Далі йдуть вольові стани піддатливості впливу та покірливості. Також у семантиці новогрецьких прислів’їв відображено вольові категорії цілеспрямованості, сили волі та слабовілля. Найменш розкритими вольовими поняттями в новогрецькому паремійному фонді мови виявилися рішучість і впертість.

Розглянемо способи перекладу прислів їв. Найбільш вдалим і повним уважається переклад за допомогою еквівалента. Повним прислівним 
еквівалентом називається переклад, коли в мові перекладу є прислів'я, рівноправне за змістом, функціями та стилістичними характеристиками прислів'ю оригіналу та яке співпадає з ним повністю або у своїй основі за образним змістом. Досить часто його називають моноеквівалентним перекладом, який, у свою чергу, ділиться на два види:

a) абсолютні моноеквіваленти або повний еквівалент.

Випадки абсолютних моноеквівалентів порівняно нечисленні. Такі паралельно існуючі в різних мовах прислів'я зазвичай є запозиченнями, наприклад:

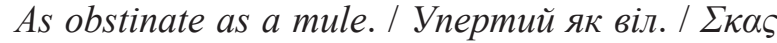

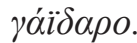

Такий спосіб перекладу прислів”їв вимагає від перекладача високого рівня знання культури особливостей двох мов, адже треба перекласти прислів'я так, щоб воно було зрозумілим носію іншої мови, а значить, представнику зовсім іншої культури;

б) відносні (часткові) моноеквіваленти.

При використанні такого способу перекладу прислів’їв моноеквівалентною в мові перекладу залишається лише одна частина прислів’я, а інша частина набуває того ж самого значення за допомогою використання того ж образу, дії чи стану, зазначених у прислів'ї вихідної мови. Такі прислів'я мають ідентичний компонентний склад, синтаксичну структуру, конотативний фон, засновані на близьких образах. Це ілюструють такі прислів'я:

If a sheep loops the dyke, all the rest will follow. I Куди одна вівия, туди і вся отара;

Куди дерево підрубане, туди воно й падає. I Where the tree falls, there it must lie;

$\Sigma \tau \eta \beta \rho \alpha ́ \sigma \eta ~ \kappa o \lambda \lambda \dot{\alpha \varepsilon l ~ \tau o ~ \sigma i \delta \varepsilon \rho o . ~ I ~ S t r i k e ~ w h i l e ~ t h e ~}$ iron is hot. / Куй залізо, поки воно гаряче;

в) відносні моноеквіваленти 3 повною розбіжністю в образності.

На відміну від попередньої групи, відносні моноеквіваленти 3 повною розбіжністю в образності становлять найбільш численну групу прислів 'їв. Такі прислів'я мають близький конотативний фон, але засновані на іншій образності. Такий спосіб перекладу прислів”ї є найбільш поширеним у перекладацькій практиці, якщо розглядати лише еквівалентний переклад паремій. Наведемо такі приклади прислів”їв із цієї групи:

As a tame cat. / Як мокра курка;

If he cannot bite, he scratches. / Не києм, mo палицею;

As changeable as weathercock (sea, moon). / Cim n'ятнииь на тиждень;

Gather your rosebuds while you can. / Kоси коса, поки роса.

Обрані нами прислів'я збігаються за значенням, стилістичним забарвленням i близькі за образністю, але розбіжні за лексичним складом.
У тих випадках, коли немає відповідного еквівалента прислів'ю вихідної мови або ж відповідне прислів'я має яскраво виражене національне забарвлення чи розходиться 3 прислів'ям мови перекладу в стилістичному відношенні, доводиться вдаватися до вільного перекладу, тобто до калькування або до описового перекладу прислів'я.

До описового перекладу варто вдаватися, коли інші варіанти перекладу неможливі, тобто відсутній еквівалент. Розглянемо декілька прислів”ї, перекладених описовим способом:

Absence is a shrew. - Посилання на відсуmність - аргумент боягузів;

By the street of "Bye-and-Bye" one arrives at the house of "Never". - Проявами слабовілля та зволікання нічого не досягнеш;

Open not your door when devil knocks. - He nidдавайся спокусі [10];

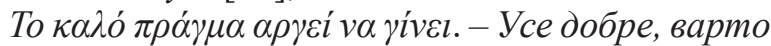
почекати [11];

As a man with plenty of guts. - Так говорять про вольову та рішучу людину [10].

Коли прислів'я вихідної мови насичене лінгвокультурним матеріалом, експлікація стає найбільш зручним варіантом перекладу для досягнення розуміння між носіями різних мов. Однак при використанні такого перекладацького прийому втрачається образна асоціативність будьякого прислів'я.

Прийом кальки при перекладі ілюструють такі прислів' я:

Nothing is impossible to a willing heart. - Toü, хто прагне, зможе досягти чого завгодно [10];

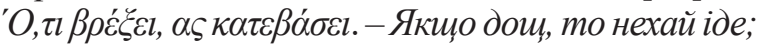

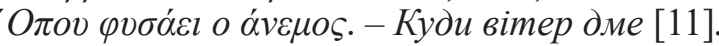

Дослівний переклад - це останній варіант перекладу прислів’їв з точки зору перекладацької компетентності й адекватності перекладу:

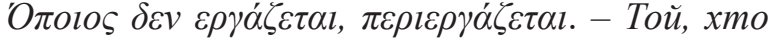
не працює, тільки спостерігає [11];

He that dares not venture must not complain of ill-luck. - Tой, хто не відважився ризикнути, не повинен скаржитися на погану вдачу;

He who shoots often, at last shall hit the mark. Хто часто стріляє, той колись влучить у изіль [10].

Висновки й перспективи подальших розробок. Таким чином, опрацювавши способи перекладу прислів”їв на матеріалі трьох мов, ми дійшли висновку, що найбільш уживаними є описовий переклад (40\%), частковий еквівалентний переклад (20\%) і повний прислівний еквівалент $(15 \%)$, а найменш уживаними способами перекладу прислів'їв виявилися калька (15\%) і дослівний переклад (10\%).

Перспективою подальших досліджень убачаємо проведення подібного аналізу на матеріалі інших категорій на позначення стану людини. 


\section{ЛІТЕРАТУРА}

1. Потебня А.А. Из лекций по теории словесности. Басня. Пословица. Поговорка. Харьков : Тип. К. Счасни, 1894. 164 с.

2. Кунин А.В. Фразеология современного английского языка. Москва : Международные отношения, 1972. 289 с.

3. Виноградов В.В. Русский язык. Грамматическое учение о слове. Москва : Высшая школа, $1972.614 \mathrm{c}$.

4. Пермяков Г.Л. Основы структурной паремиологии. Москва : Наука, 1988. 236 с.

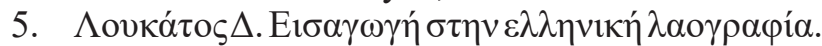

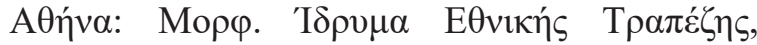
1977. $353 \sigma$.

6. Kuusi A.L. Towards an International Type - System of Proverbs. Proverbium, Yearbook of International Proverb Scholarship. Vermont : University of Vermont, 1972. № 19. P. 698-736.

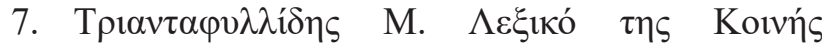

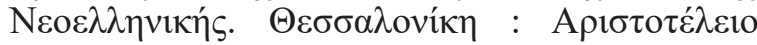

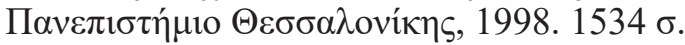

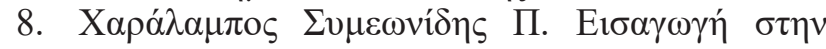

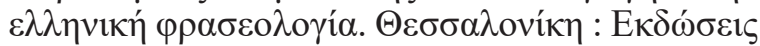
$\mathrm{K} \Omega \Delta \mathrm{IKA} \Sigma$, 2000. $122 \sigma$.

9. Українські приказки, прислів'я і таке інше / впорядкував М. Номис. Київ : Либідь, 1993. 768 c.

10. Баранцев К.Т. Англо-український фразеологічний словник. Київ : Знання, 2005. 1056 с.

11. Новогрецькі тематичні прислів'я. URL: http://www.gnomikologikon.gr/greek-proverbs. php?page=8\#axzz2PgKMJhZd.

\section{REFERENCES}

1. Potebnya, A.A. (1894) Iz lektsiy po teoriyi slovesnosti. Basnya. Poslovitsa. Pogovorka [From lec- tures on the Theory of literature. Fable. Proverb. Saying]. Kharkov: Type. K. Schasni.164 p.

2. Kunin, A.V. (1972) Frazeologiya sovremennogo angliyskogo yazyka [Phraseology of modern English]. M.: International relations. 289 p.

3. Vinogradov, V.V. (1972) Russkiy yazyk. Grammaticheskoye ucheniye o slove [The Russian language. Grammatical teaching about the word]. M.: Higher school. 614 p.

4. Permyakov, G.L. (1988) Osnovy strukturnoy paremiologiyi [Fundamentals of structural paremiology]. M.: Nauka. 236 p.

5. Loukatos, D. (1977) Eisagogi stin elliniki laografía [Introduction to Greek folklore]. Athens: Morph. National Bank Foundation. 353 p.

6. Kuusi, A.L. (1972) Towards an International Type- System of Proverbs. Proverbium, Yearbook of International Proverb Scholarship. Vermont: University of Vermont, vol. 19. P. 698-736.

7. Triantaphyllidis, M. (1998) Lexiko tis Koinis Neoellinikis [Dictionary of Common Modern Greek]. Thessaloniki: Aristotle University of Thessaloniki. $1534 \mathrm{p}$.

8. Charalampos Symeonidis, P. (2000) Eisagogi stin elliniki fraseología [Introduction to Greek phraseology]. Thessaloniki: KODIKAS Publications. $122 \mathrm{p}$.

9. (1993) Ukrayinski prysliv'ya ta prykazky i take inshe [Ukrainian proverbs and sayings and so on] / edited by M. Nomys. K. : Lybid, 1993. $768 \mathrm{p}$.

10. Barantsev K.T. (2005). Anhlo-ukrayinskyy frazeolohichnyy slovnyk [English-Ukrainian phraseological dictionary]. K.: Znannya. 1056 p.

11. Novohretski tematychni prysliv'ya [Modern Greek thematic proverbs]. URL: http://www.gnomikologikon.gr/greek- proverbs.php?page $=8 \#$ axzz2PgKMJhZd. 